\title{
Urgences
}

\section{Détournements (extraits de Le cour spirales du tournesol)}

\section{Louky Bersianik}

Numéro 33, octobre 1991

Poésies parallèles : France - Québec

URI : https://id.erudit.org/iderudit/025670ar

DOI : https://doi.org/10.7202/025670ar

Aller au sommaire du numéro

Éditeur(s)

Urgences

ISSN

0226-9554 (imprimé)

1927-3924 (numérique)

Découvrir la revue

Citer ce document

Bersianik, L. (1991). Détournements (extraits de Le cour spirales du tournesol).

Urgences, (33). https://doi.org/10.7202/025670ar d'utilisation que vous pouvez consulter en ligne.

https://apropos.erudit.org/fr/usagers/politique-dutilisation/ 


\section{Détournements \\ (extraits de Le cœur spirales du tourneso) \\ Louky Bersianik}

La conque de ton oreille appuyée au centre de l'hélianthe tu écoutes

Labyrinthe de l'entendement sur les cloisons de la préhistoire tu perçois les violoncelles tristes d'une ammonite fossile inconnaissable à jamais

Les vingt et une cymbales de sa colère indestructible t'ont percé le tympan

Vibration vibration répercussion sans fin des malentendus 
82

\section{II}

Une dent contre la langue tu t'attaques aux mots couverts t'insinues sous l'ivoire étymologique trouver la réalité à la racine éclaire le sous-entendu L'œil amarré à l'existence tu cherches les tropes où vivent certains mots dans leurs coquilles vides

Tu as beau regarder le jaune se dérobe tu ne vois

que du blême et du noir 


\section{III}

C'est vers un soleil héliporté depuis l'aube que se tourne l'héliotrope Les pales déchiquettent le silence au croisement des spirales déplacement incessant de paroles ailes de pyrale et battement d'arrache-cour Ton cœur est une pyramide renversée qui sera dévorée de la base au sommet au croisement des spirales 
84

\section{IV}

La peau de la fleur affligée

en perte de douceur

avorte d'une feuille littérale

et produit l'épine

La fleur capitulée entre

lentement dans un mouvement

de pavane et cette infante défunte

se détourne du temps

La peine ne pouvant s'atteindre

tourne au verso des horloges

La colère se touche du doigt

ainsi va-t-elle comme l'écriture

dans le sens des aiguilles 
Tu es une fleur à capitules jaunes

et tu es gigantesque

Tu as un coeur d'Erinye polaire

blême de colère noir de peine

Insecte vivant dans le feu

ou fossile vivant

d'un cerveau de nautile

la Bienveillante

détourne la Furie de son sens

et de son cri efface derrière elle toute odeur de fauve

Elle n'a plus de parfun la fleur de rhétorique en perte d'onglet 